\title{
街並み景観データベースを活用した歴史的街並み再生の方法論に関する研究
}

- 岡山県高梁市における景観構造の視覚化と町並み助成制度による修景効果の検証一

\section{A STUDY ON THE METHODOLOGY FOR REGENERATION OF HISTORICAL TOWNSCAPE UTILIZING URBAN DATABASE}

Test of the effectiveness of the subsidy program for townscapes and in the city of Takahashi, pref. Okayama

古市 修*, 小林正美**, 泉山畦威***, 野口弘 行**, 内 山善明****
Osamu FURUICHI, Masami KOBAYASHI, Rui IZUMIYAMA,
Hiroyuki NOGUCHI and Yoshiaki UCHIYAMA

\begin{abstract}
Recently the "Landscape Law" supports the implementation of local city's urban design plan. Though for consensus making between the government and the stakeholders, there have been few visual tools to communicate together on the existing and new urban design. This research deals with a new analytical and generative methodology for townscape renovation and the verification of the effectiveness of the subsidy program based on Design Code. By analyzing and visualizing the distribution of the groups of similar housing types with mathematical graphs, this study clearly shows the chronological changes of the urban fabrics and how to control them
\end{abstract}

Keywords : Visualization, Townscape、Historical Streetscape, Regeneration of Townscape, Landscape Structure 視覚化, 都市景観，歴史的街並夕，街並夕再生，景観構造

\section{1. 研究の背景}

世界遺産の指定や近代化産業遺産などが一般のニュースに頻繁に 載るように、地方都市における歴史的街並みの保存再生に対する 人々の関心は近年ますます高まっていると言える。1975 年に制定さ れた伝統的建造物群保存地区の指定や都市景観条例に代表される景 観コントロールの手法は、1990 年代に国の制度設定に先立ち、自治 体の自主条例等の検討が活発に行われ、最終的に 2005 年に制定され

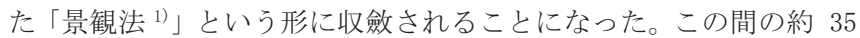
年に街並み景観に対する考え方も少しずつ変化してきている。当初 は、美観や文化財的な意味合いから、外観については表層的に凍結 保存し、あたかも時間が流れていないかのような街並みが美しいと

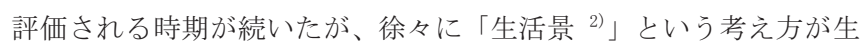
まれ、地域固有の文化や内部の生活がにじみ出した生きた街並みの 重要性が評価されるようになった。特に 2008 年に制定された、いわ

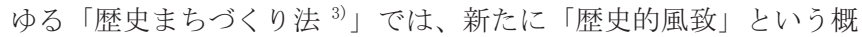
念が導入され、「歴史的価值の高い国民共有の文化的な資産と地域の 歴史・文化を反映しつつ、営まれる人々の活動をあわせたもの」と いら定義が与えられ、まち自体が長年保全してきた文化的行事の背
景として美しい歴史的街並みが存在すべきであるという考え方が明 確に打ち出されたのである。また、地方分権が進む中で、各都市の 界隈や通りが固有の個性を打ち出すことが都市観光の活性を導き、 まちおこしの原動力になるというシナリオが当たり前のように語ら れる時代が到来した。

このような景観に対する評価軸の変動に対して、学術的な評価基 準は必ずしも充分に議論し尽されてきたとは言えない。表層的な街 並みの連続性については、守山、門内 ${ }^{4)}$ に代表されるような街並み 調查から得られた立面情報から記号的記述により街並みの要素を列 挙し、その関係性を視覚化するような記号論的な分析手法が新規性 のある方法論として評価された。一方で、新しい街並みコントロー ルや住民の合意形成の支援ツールとして、模型によるシミュレーシ ヨン、CG、アニメーションやバーチャルリアリティー（VR）等によ

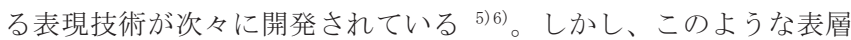
的な街並みの評価軸に加えて、「生活景」などのような生活や文化の にじみ出した「生きた街並み」の継時的変化や、二次元的広がりと しての建物群に対する景観政策、ないがしろにされがちな一般市街 地の景観コントロールなどについての分析方法や合意形成のための
* 明治大学理丁学部建築学科 研究生.丁修

** 明治大学理工学部建築学科 教授.工博

*** (株アルキメディア設計研究所 工修

**** 明治大学理工学部建築学科 研究員·工博
Researcher, Dept. of Architecture, School of Science and Technology, Meiji Univ., M. Eng. Prof., Dept. of Architecture, School of Science and Technology, Meiji Univ., Dr. Eng. ARCHI-MEDIA Architects \& Associates Co., Ltd.

Researcher, Dept. of Architecture, School of Science and Technology, Meiji Univ., Dr. Eng. 
支援ツールは未だ開発されていないのが現状である。

本研究では、まず、生活景を客観的に分析する前段階として、表 層的な評価軸と共に、建物形式に生活や文化、ライフスタイル等が 顕在化されていることに着目した。そして、二次元的広がりの中で 共通の「特徽的景観要素」を持った建物群を「まとまり」という概 念で位置づけ、マクロ的視点から見た様々なタイプの建物群（まと まり）の分布変化とミクロ的に見た街並みの連続性とを橋渡しする 分析方法および評価手法を開発することを試みた。また、今までの 景観論ではあまり取り上げられなかった、地域における「屋敷形式」 と「町屋形式」の対照的な存在の偏りや、新建材を用いた一般住宅 の分布状況を等価に取り上げて可視的に表現することで、これから の行政が策定する景観政策や住宅政策に資すると同時に、住民など のステークホルダーと呼ばれる人たちにも分かりやすい評価方法を 提供することを目指している。

本研究の対象地である岡山県高梁市は、人口約 39,000 人の典型的 な地方中小都市であるが、重要文化財である備中松山城をシンボル とし、江戸時代前期 (1616年) に商工業者を誘致した頃からその城下 町として栄え、明確な都市構造を構築したことで有名である。現在 でも近世城下町の明確な都市構造を残し、特徵のある町割りや歴史 的街並みが現代的生活と共存しているが、近年新規建替えも増加し つつあり、早めに景観コントロールの手を打たなくてはいけない状 況にある。そのこともあり、2009年にはまちをあげて「歴史まちづ くり法」の計画認定に向けて取り組み、2010年にはその認定を受け ることができた ${ }^{7)}$ 。近々、景観計画を策定する予定であることから、
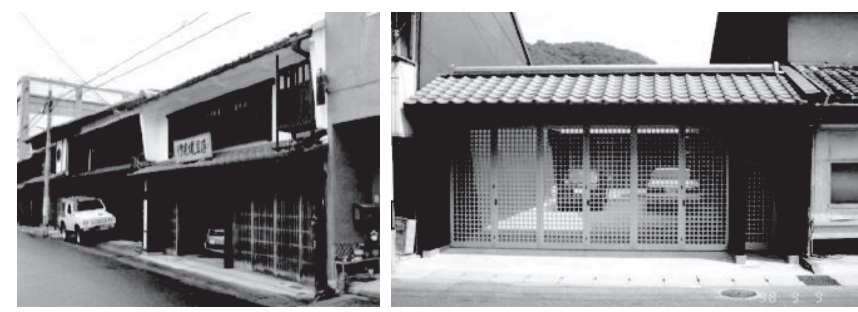

図1 本町の街並み 図 2 駐車場設置の門による街並み修景
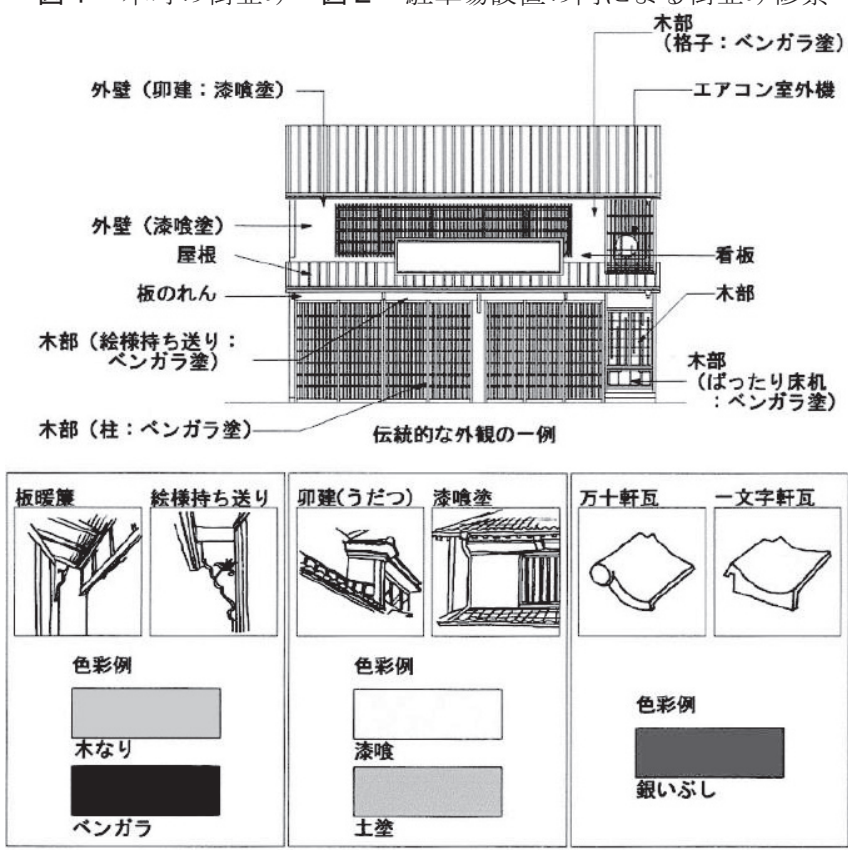

図 3 本町地区におけるデザインガイドライン
行政、市民と協働しながら合意形成を図り、景観コントロールの方 法論を検証していく必要がある。

これまで筆者らを含めた明治大学小林研究室は、1993年から現在 までの約19年間毎年学生たちを引率し、高梁市で継続的に街並みの 調查研究を行ってきた。また、1993年以前にも本町地区（図1）を 中心に東京芸術大学前野研究室 ${ }^{8)}$ が重要伝統的建造物群保存地区指 定のための基礎調查を行っており、その成果は筆者らが景観データ ベースを構築するにあたり重要な基盤となっている。同研究室が毎 年研究活動を積み重ね、行政や商工会議所、青年会議所などに対し て、短期集中合宿で建築やまちづくりの提案を「シャレットワーク ショップ 9)」形式で行い、(1)住民との合意形成で具体的なデザイン ガイドライン ${ }^{10)}$ を策定（図 3 ）し、(2)そのモデルとして門と小池邸 を設計し（図 2)、(3)蔵の改修に参加して高梁観光物産館として再生 したことなどが特筆される ${ }^{11}$ 。

\section{2. 研究の位置づけ及び目的}

本研究が着目寸る「特徵的景観要素」の群とした「まとまり」に ついては、小浦により、詳細な調査、報告が行われている ${ }^{12)}$ 。その 一部としては、正本・小浦 ${ }^{13)}$ は歴史的街並みの一街区ごとに「まと まり」を抽出し、伝統的な町家よりも町家の䨌囲気を残寸建物のま とまりが重要であり、内部よりも外部や表層的な要素が䨌囲気を伝 えることが重要としている。そのほか、土久・山本 ${ }^{14)}$ は日本の歴史 的景観において形態的なまとまりと変化に注目し、「まとまり」の要 因の多くは地形的要素であるとし、「まとまりと変化」の視点から建 造物の形態面から景観を構成する要素を把握することは景観政策の 代替的方向性や施策選定の評価基準になるとしている。また、色彩 による「まとまり」の影響から広告的なファサードの色彩規制を木 多ら ${ }^{15)}$ は提案しており、奥 ${ }^{16)}$ は視覚効果が心理的に作用し「まと まり」をさらに良くする効果について提案している。しかし、本研 究のように、景観データベースのデータを元に、線的な通りに加え て、面的な城下町のような市街地全体の「特徴的景観要素」の群之 した「まとまり」を視覚化し、歴史的街並み再生の方法論に迫った 研究は見られない。

また、本稿の分析手法として用いる「まとまり分布グラフ」は、 密度を図形化して表寸手法であるが、既存の手法としては「カーネ ル密度推定法」17) という、大都市圈などを分析対象とし、膨大な統 計等の情報を関数などで高速に処理する手法でも適用可能である。 しかし、本研究が対象とする歴史的街並みの景観を分析する手法と しては、「特徴的景観要素」の群とした「まとまり」という主観的要 素を基軸とした対象を扱うため、今後の景観研究の中での祭事や生 活のにじみ出し等の無形物や潜在的な傾向の視覚化等の分析手法へ の応用も考慮し、これまでの都市構造の視覚化の研究の蓄積 18) 19) 20) から客観性を持ちながら、「まとまり分布グラフ」という独自に手法 を開発することによって、景観構造の視覚化を試みる。

本研究は、高梁地区の長年にわたる街並み調査結果からまとめた 景観データベースを元に建物形式を類型化し、その後に「特徽的景 観要素」の集積を示した「まとまり分布グラフ」を定量的に視覚化 することで、行政や住民が議論を共有できる概念的なプラットホー ムを構築することを主要な目的とした。その結果、景観をコントロ ールするデザインガイドラインやそれに基づく町並み修景助成制度 


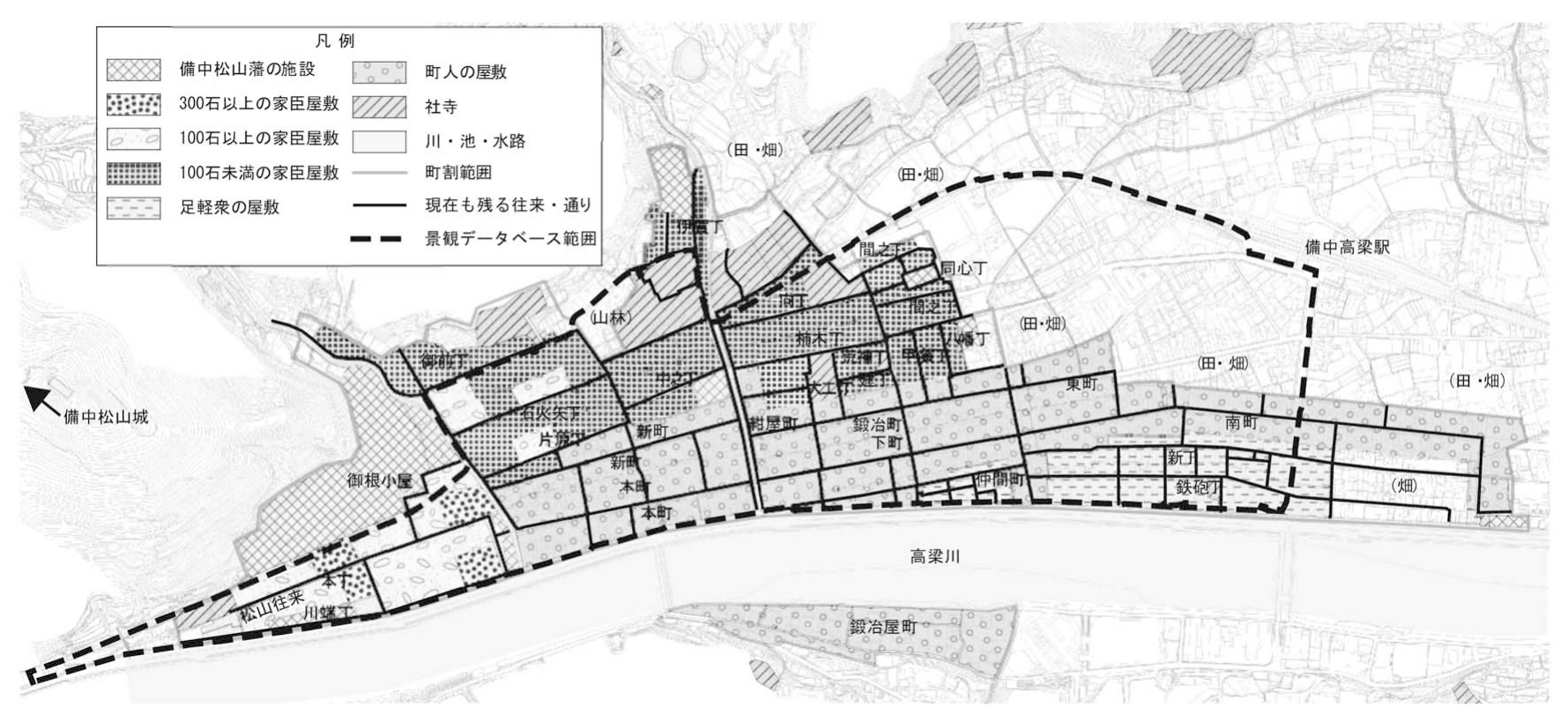

図4旧城下町の町割と現市街地の重ね合わせ図と景観データベースの対象範囲注1）7)

である「高梁市歴史的町並み保存地区整備事業(以下、町並み助成)」 による街並み修景の効果を検証することを具体的な目的としている。

\section{3. 研究の方法}

本研究は、以下の手順により研究を進めた。

(1)街並み調査により高梁地区の景観データベースを作成する。

(2)そのデータを元に、住宅形式の類型化（伝統継承の有無／住宅形 式4タイプ）を行う。

(3)類型化した住宅形式毎に地図上にプロットした分布図とその集積 度を定量化した立体的な「まとまり分布グラフ」を作成し、分布 状沉を検証する。

(4)1999 年に創設されたデザインガイドラインに基づく町並み助成 の区域として指定され、特に「まとまり」が顕著な本町地区を対 象に「まとまり分布グラフの断面ライン」と「連続立面図」の重 祊合わせ図を作成する。

(5)（イ）町並み助成制度創設前の 1998 年モデルと、（ロ）制度創設 10 年以上経過し、修景実績のある 2010 年モデル、(ハ) 仮想モデ ル（修景物件を修景せずに商品型住宅に建替わったと仮定）を比 較検証し、デザインガイドラインや町並み助成による修景効果を 検証する。

(6)今後の高梁市における歴史的街並み再生の方法論を提案する。

\section{4. 岡山県高梁市の概要及び近世城下町の都市計画}

高梁地区は岡山県の西部を流れる高梁川の中流域の三方を山に囲 まれた盆地に位置し、備中松山城をシンボルにその城下町として栄 えてきた。備中松山城の起源は鎌倉時代の築城に遡るが、城下町自 体は江戸時代前期以後に発展した（図 4)。現在の高梁市は 2004 年 の市町村合併により、旧高梁市 (高梁地区)、旧有漢町、旧成羽町、 旧川上町、旧備中町の一市四町が一つとなった。

また、現在の高梁地区の都市計画の基盤は、江戸時代に備中松山 城を中心とする城下町の骨格が近世都市計画として形成されたこと

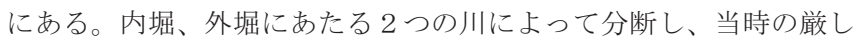

い身分階級によって住む区域を限定した都市計画が施行され、武家 屋敷界隈・町人界隈・下級武士界隈などの明確な特徵ある地区は、 現在でも充分に認識することができる。しかしながら、近代に入っ て備中高梁駅の建設により、高梁市の中心が備中松山城から南方の 備中高梁駅近辺に変わり、それに伴い新たな用途地域が指定され、 城下町的都市構成から近代都市計画に基づく構成へと都市の構造が 変化した。その結果、ライフスタイルの変化や建替えなどもあり、 地区によっては歴史的な印象が薄れたが、中でも商家町の代表筋で ある本町地区は、現在でも城下町の雾囲気を強く残している。

前述したが、高梁市は 2010 年に「歴史まちづくり法」の計画認定 を受け、「高梁市歷史的風致維持向上計画」4)を策定した。今後 10 年間は、歴史的街並みを保全するハード整備だけでなく、伝統民俗 芸能などの伝統継承・保存団体の支援などのソフト事業も行い、歴 史的街並みの保存再生の更なる展開を図っていく状況である。

\section{5. 景観データベースの概要及び住宅形式の類型化}

\section{(1) 景観データベースの概要}

1993 年以来の調查研究に加え、2009 年から 2010 年にかけて、筆 者らを含めた明治大学小林研究室は集中的な街並み調查を行い、そ の際に高梁地区の旧町割りを概称網羅し、旧市街に位置する住宅建 築の集積している範囲を対象とし（図４）、景観データベースを構築 した。調査内容は、(1)建物の間口、高さなどの立面寸法の計測、(2) 建物の立面及び側面の静止画記録、(3)通り毎の街並み動画記録を行 い、(4)その調査結果をもとに通り毎の連続立面図を作成し、景観デ ータベースを構築した。全住宅件数 1647 件ある本景観データベー

表 1 景観データベース建物カルテの一例

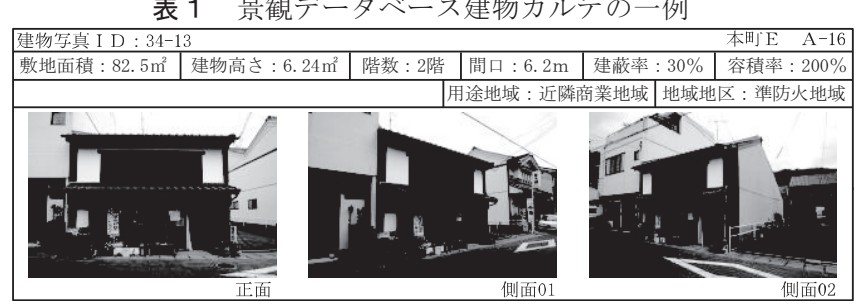


スは、景観構造の視覚化などの街並み再生の分析・研究のための基 礎資料としている（表 1 ）。

得られた調查結果をデータベース化するにあたり重要視したのは、 単なるリス卜化ではなく、それら建物の立面情報と位置情報とを合 せ持つデータベースの作成である。街並み景観を分析する際に重要 なのは建物の連続性や集合のあり方であると考え、各建物が都市の どの位置にどのように配置しているかを視覚的に認識可能なデータ ベースとすることを試みた。今後は GIS (地理情報システム)により 管理していくことを目指し、行政機関と共に、まちづくりにおいて より効果的に活用可能なデータベース構築の検討を行っており、本 研究は活用手法の一つを示すものとなっている。GIS を用いること で、継続的に街並み調査のデータを管理・更新することや、第三者 との情報共有が可能になると考えられる。

\section{（2）住宅形式の類型化とその指標}

前述のように、高梁市は近世都市計画を元にした城下町であり、 街中に現存する主な建築形式は住居である。備中高梁駅が建設され た後、近代都市開発の中で、駅前付近の商店街などでは、商業施設 が集積して立ち並んではいるが、その他の地区の商業施設は、商家 町を中心とした店舗兼用住宅である。また、高梁市の住宅は外観上 の特徵的な表現が街並み景観に対しても大きな影響を与えており、 特に住宅形式による表情の違いが明確に現れている。そこで、住宅 形式から「特徵的景観要素」を抽出するために、高梁地区の住宅形 式の類型を、景観データベースを元に、「町家形式」・屋敷形式」・商 品型住宅形式」・集合住宅形式」の 4 種類とした。また、建築形式

表 2 類型化した住宅形式とその特徴

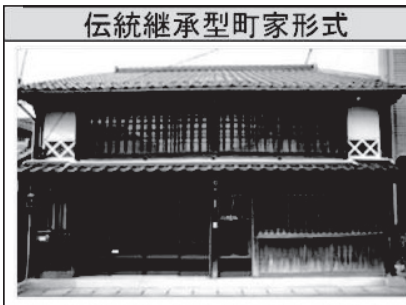

木材や瓦などの伝統的素材を使用したも ので、商家が多い。現在は店舗を閉店し 駐車場や居室にしている例が多い。 伝統継承型商品型住宅形式

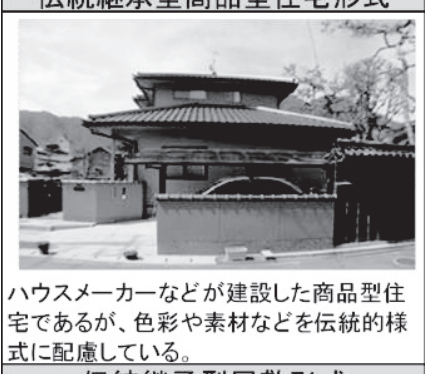

伝統継承型屋敷形式

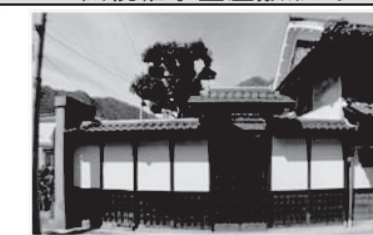

伝統的素材を使用しながら建設された昔 ながらの屋敷。比較的敷地の規模は大き く、道路側には門や塀を設け、建物と塀の 間に中庭を設ける配置がー般的である 非伝統継承型町家形式

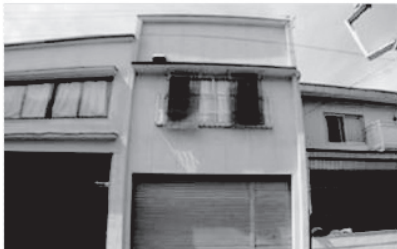

用途や建築形態は町家ではあるが、コン クリートなどの工業製品の仕様で伝統継 承をしているわけではない 非伝統継承型商品型住宅形式

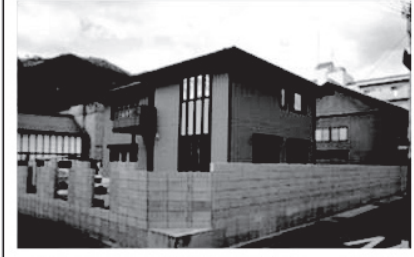

ハウスメーカーなどが建設した一般的な 商品型住宅。素材などの配慮はなく、全 国の他の地域にもあるような住宅である 非伝統継承型集合住宅形式

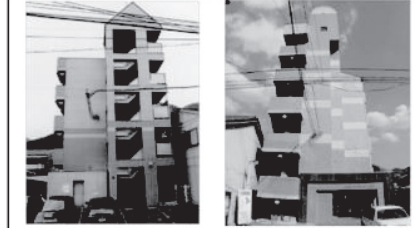

1990年代の大学誘致の際に、建設された 学生アパートを中心とした集合住宅。色彩 や素材に配慮はなく、周囲に中層の建物 がないため、圧迫感を与えている。
の類型化に加えて、歴史的な様式の住宅を「伝統継承型」、近代様式 の住宅を「非伝承継承型」としてクロス類型を図り、計 8 種類の住 宅形式に類型化を図ったが、「伝統継承型集合住宅形式」と「非伝統 継承型屋敷形式」は存在せず、それを除いた 6 種類の類型化を行っ た（表 2 ）。類型化した指標に関しては、類型の判断基準として、景 観データベース内の住宅を対象に、東京芸術大学前野研究室の調査 報告書 ${ }^{5)}$ を元に建築様式の特徵を参考にした。伝統・非伝統継承型 の判断基準として、基本的には外観に木材・木質材料や瓦などの伝 統的建築様式に基づく素材を用いていることを条件とし、非伝統的 継承型は、コンクリートやタイルなどの工業製品の素材を用いるこ とを条件とした。町家形式の判断基準としては、1階の道路に面し た居室を、店舗を営んでいた土間の形式（現在のライフスタイルヘ の転換のため、駐車場にしている例もある）にし、その奥と 2 階を 居室にしている形式で判断した。現状ではほとんど店舗をやめ住宅 の用途とした町家が多い。商品型住宅はハウスメーカーが建設した 住宅様式を判断している。屋敷形式は、道路に面する場所に門や塀 を設け、建物をセットバックし、その間に中庭を設ける形式と判断 した。集合住宅は判断基準が明確であるが、ひとつの建築の中に複 数の戸数の住宅があるものと判断した。

\section{6. まとまり分布グラフの作成方法と分布状況の分析}

\section{（1）まとまり分布グラフの作成方法}

類型化した住宅形式の集積量を単位面積あたりの要素数と定め、 集積した「特徴的景観要素」を視覚化する方法として、まとまり分 布グラフという手法を開発し、これを用いて景観構造の視覚化を試 みた。まとまり分布グラフの作成方法を図 5 に示す。

(1)調查区域全体に、観測点の基本となる $20 \mathrm{~m}$ 解析メッシュを設定 した (図 5-a)。高梁地区では江戸時代の区画が現在も明確に残って おり、町家形式の住居が町割りの基本となっている。町家形式の住 居の奥行き（長手方向）がおよそ $20 \mathrm{~m}$ 程度であることから、解析メ ッシュの 1 マス内に 1 軒含むことのできる $20 \mathrm{~m}$ 解析メッシュでの測 定を行うこととした。

(2)景観データベースから、類型化した住宅形式毎に地図データに プロットを行い、平面分布図を作成した（図 5-b)。地図上のプロ ット位置については、建物のファサードだけではなく、側壁面や屋 根面など建物全体で景観を構成していることを重視し、ファサード の位置ではなく、建物の平面形状の重心にプロット寸ることとした。

(3)事前に行った実験において、道路中心から街並みを見た時に、 被験者中の 8 割以上が住宅形式の類型化や伝統継承しているか否か の判別ができた距離が約 $40 \mathrm{~m}$ であったことから、ある観測点に対し て建物が景観に強く影響する範囲を観測距離とし、40mで設定した。 $20 \mathrm{~m}$ 解析メッシュの交点を観測点とし、各観測点から観測距離であ る半径 $40 \mathrm{~m}$ 以内に存在する類型化した住宅形式毎の要素数をカウ ントした。(図 $5^{-}$c $)$

(4)観測点でカウントされた要素数に定数を掛け、その観測点の持 つ高さとして数值化した（図 $5-\mathrm{d}$ )。

(5)全ての観測点において、要素数を高さに数值化して行き（図 $5-\mathrm{e}) 、 そ れ ら を 20 \mathrm{~m}$ 解析メッシュの高さとして入力し、起伏のつい た面状の 3 D グラフ「まとまり分布グラフ」を生成した（図 5-f)。 $20 \mathrm{~m}$ 解析メッシュの観測点に対し、観測距離を $40 \mathrm{~m}$ としたことで要 
素を重複してカウント寸ることになるが、本グラフのまちづくりに おける合意形成支援ツールとしての役割を考慮し、仮に観測者がそ の観測点に立った際の特徵的景観要素を、定量的に連続して表記す ることを重視した。このまとまり分布グラフにおいて、グラフが他 の場所よりも高く、ある一定範囲の広がりを持っているとき、その 場所は「要素の集積量が多い」こととなり、視覚的には「ある共通 の特徵的景観要素が集積した界涱」となっていることが分かる（図 5-f)。本研究では、要素の集積の様子を示した一定範囲の広がりの ことを「まとまり」とし、また要素の集積度合いの高さ（密度）を グラフの高さとして示したものを「まとまり高さ」と呼ぶこととし

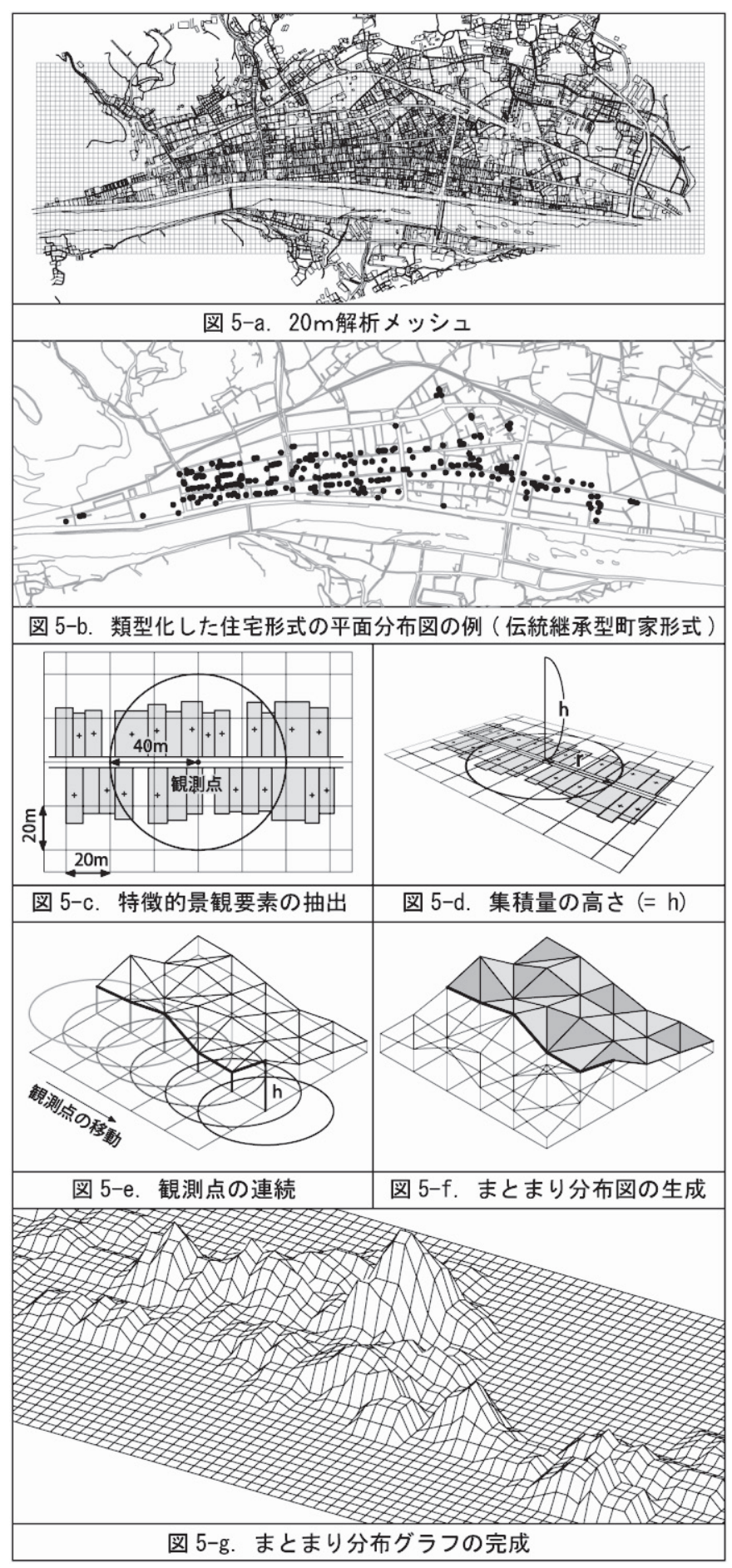

図 5 まとまり分布グラフの作成方法
た。このように、「まとまり」を定量的に視覚化することを試みた。

\section{（2）まとまり分布グラフ状況と分析}

a ）類型化した住宅形式毎の平面分布とまとまり分布グラフの分析

類型化した住宅形式について、平面分布とまとまり分布グラフを 整理した（図 6 )。「伝統継承型町家形式」は、高梁地区の中央を横 切るように南北に連なりながら平面分布をしており、まとまり分布 グラフでも同様に南北軸線上に一定のまとまり高さで分布し、まと まりが見られる。特にまとまり分布が高くなっている地域は、「高梁 市歴史的町並み保存地区整備事業」(以下、町並み助成注 2$)$ ) デザイ ンガイドラインに指定された商家町・本町地区であり、商家町は町 家が集積しており、「伝統継承型町家形式」が色濃く残り、それらが 「まとまり」を形成し街並みを保っていることがわかる。

「伝統継承型屋敷形式」は、平面分布を見ると、城下町地区の外 周にわずかに点在している。まとまり分布を見ると、点在して分布 し、まとまり高さもあまりない。これはかつて武家屋敷があった武 家町であり、江戸期より大規模の屋敷敷地であったが、固定資産税 対策による伴う相続などによる社会的な要因によって、土地が分筆 され、小規模建築が建ち並んでいることが考えられる。その結果、 まとまり分布グラフには、点在しながら景観としては孤立するよう な感じになり、「まとまり」がないと言える。

「伝統継承型商品型住宅形式」は、平面分布を見ると、高梁地区 の中心部に分布し、また高梁地区の外周部分にも点在している。ま とまり分布では、中心部にまとまりが高く分布している。これは古 くからの建築が残されており、新たに建て替える際にも伝統継承型 の住宅の様式で建て替え、伝統継承を感じさせる印象を受けるもの であった。これらは「まとまり」もあり、ほじよく景観が残されて いることがわかる。

一方、「非伝統継承型町家形式」は、平面分布を見ると、高梁地区 の中央を横切るように南北に連なりながら点在している。まとまり 分布を見ると、同様に高梁地区中心部で南北に連続して分布してい るが、まとまり高さはそれほど高くない。この住宅形式は、以前に は伝統継承型の町家形式であったと想定される住宅が、老朽化や用 途変更のための改装を行い、壁面の張替えや店舗の看板で外観を変 えたものが主となっているため、伝統継承型町家形式と同様の位置 に分布している。伝統継承型と非伝統継承型が混在して建っている ため、まとまり分布ではある程度のまとまりが見られても、伝統継 承型の方が、似たような建物形式の集積度合いが高いために、実際 の街並みを見ると埋没してしまい、非伝統継承型町家形式としての 一体感はあまり感じられず、街並みへの影響もあまり強いものでは ないことがわかった。

「非伝統継承型商品住宅形式」は、平面分布を見ると、高梁地区 の全域で多く分布しており、特に高梁地区の中心部に集中して分布 している。まとまり分布は、高梁地区全域に分布しており、さらに まとまり高さもあり、一部には突出して高い地域も見られる。これ は、住宅メーカーなどの新興住宅を中心とする建築が主である。住 宅メーカーなどの新興住宅は、高梁地区全域に「まとまり」が存在 しており、高梁地区の新規の街並み景観を形成している。

「非伝統継承型集合住宅形式」は、平面分布では、高梁地区の全 域でまばらに点在している。まとまり分布では、高梁地区の主要道 路に沿って分布しており、まとまり高さは低い。これはマンション 


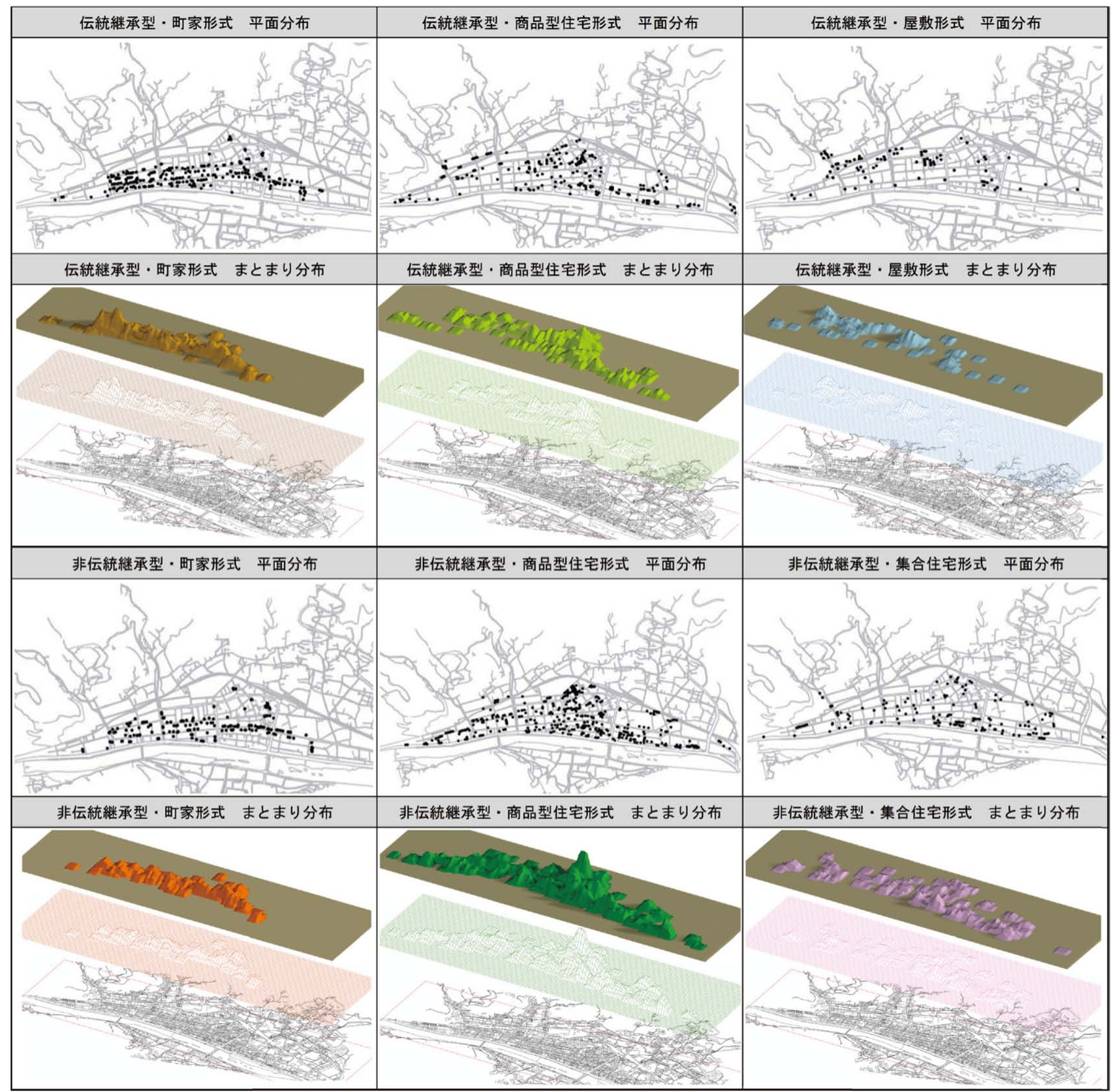

図 6 全住宅形式の平面分布及びまとまり分布グラフ

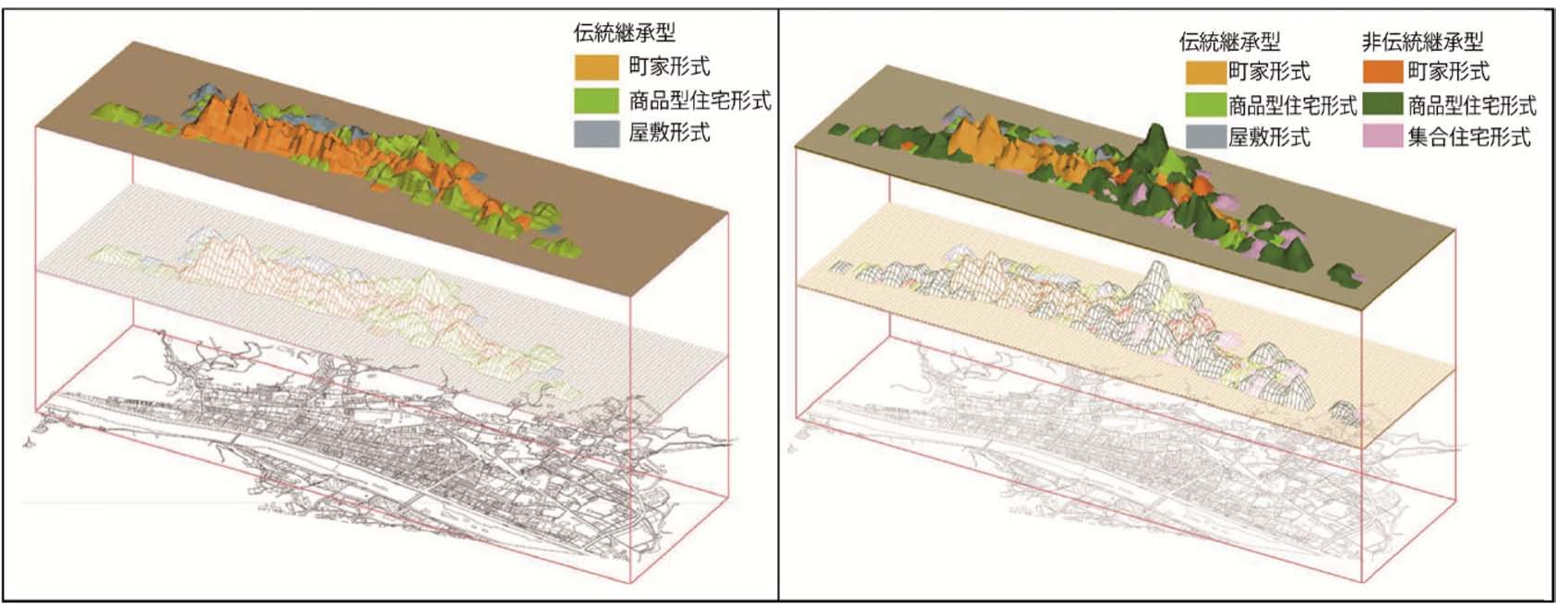

図 7 伝統継承型全住宅形式のまとまり分布グラフ（左）及び全住宅形式のまとまり分布グラフ（右） 


\begin{tabular}{|c|c|c|c|c|c|c|}
\hline & $\begin{array}{l}\text { 伝統継承型 } \\
\text { 町家形式 } \\
\end{array}$ & $\begin{array}{c}\text { 非伝統継承型 } \\
\text { 町家形式 }\end{array}$ & $\begin{array}{c}\text { 伝統継承型 } \\
\text { 商品型住宅形式 }\end{array}$ & $\begin{array}{c}\text { 非伝統継承型 } \\
\text { 商品型住宅形式 }\end{array}$ & $\begin{array}{l}\text { 伝統継承型 } \\
\text { 屋敷形式 }\end{array}$ & $\begin{array}{l}\text { 非伝統継承型 } \\
\text { 集合住宅形式 } \\
\end{array}$ \\
\hline 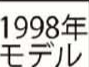 & & & & $=$ & 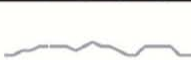 & \\
\hline $\begin{array}{l}\text { 2010年 } \\
\text { モデル }\end{array}$ & & & & 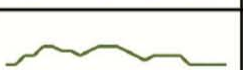 & & \\
\hline $\begin{array}{l}\text { 仮想 } \\
\text { モデル }\end{array}$ & & & & & & \\
\hline
\end{tabular}

図 8 類型化した住宅形式別まとまり分布断面ライン

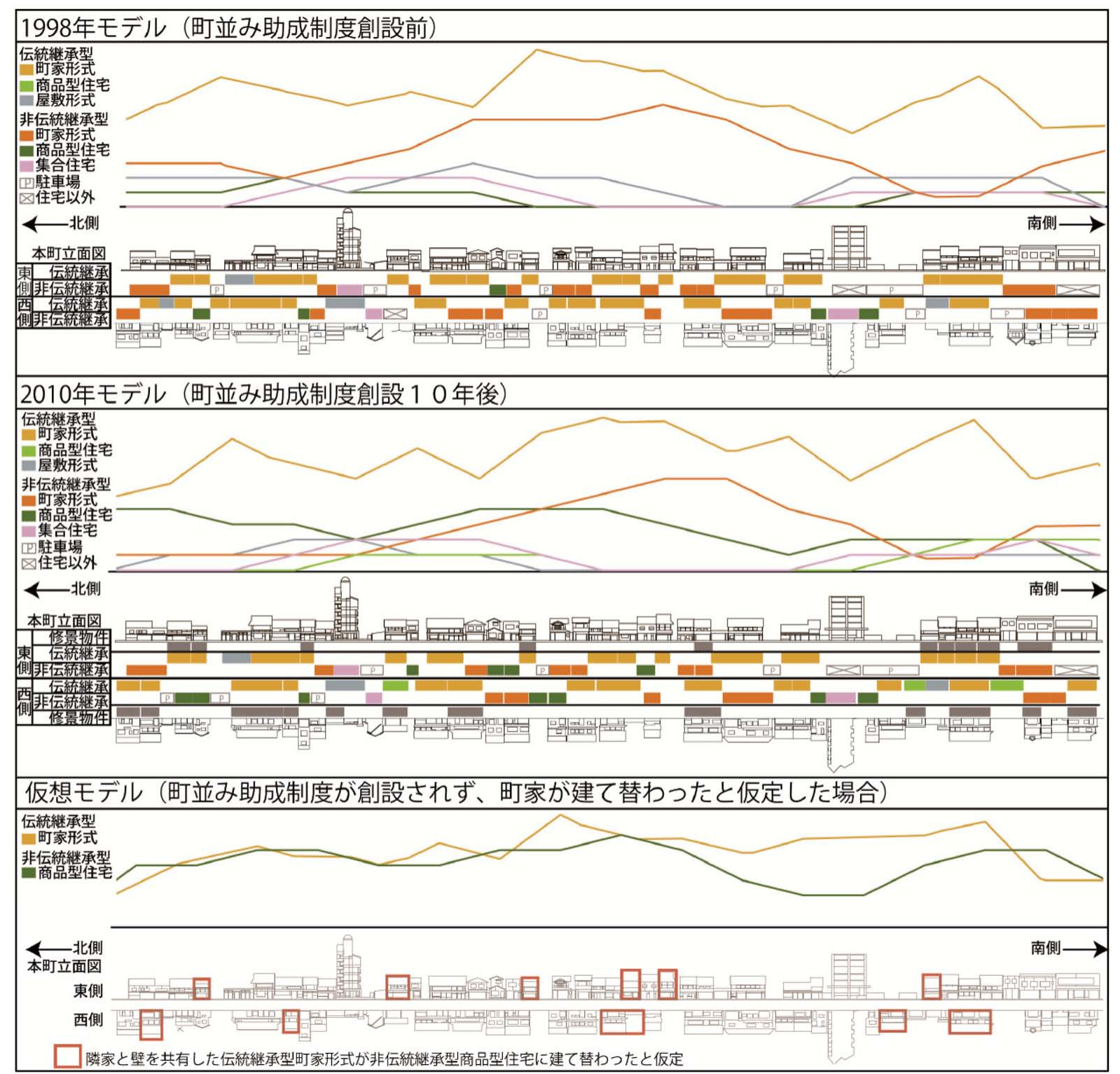

図 9 全類型化住宅形式のまとまり分布断面ラインと連続立面図の重祆合わせ分析図

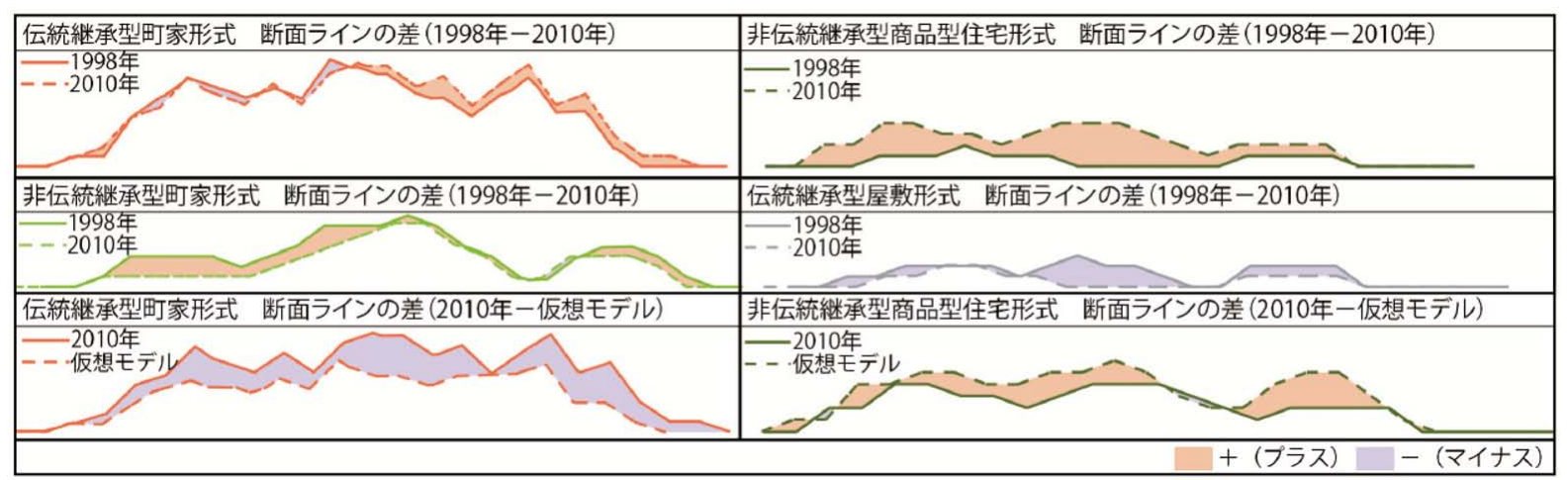

図 10 類型化した住宅形式毎のまとまり分布断面ラインの差 
や近郊にある大学の学生が住む学生アパートなどが主である。そし て「まとまり」もなく街並み一の影響も弱いと読み取れるが、現地 での街並み調查では、 2 階建ての一定の高さの街並みが揃っている 中で、 5-6 階建ての中層マンションが建っているので、街並みに 対し、大きな影響力を持つ印象が残っていた。これは先に示したま とまり分布グラフにおいては建築規模が反映されていないことが影 響している。

b ）全類型住宅形式のまとまり分布グラフの重ね合わせによる分析 住居の類型化した住宅形式のまとまり分布グラフについて、全て の類型を立体的に重祆合わせたまとまり分布を示した (図 7 右)。こ れは住居が主となる高梁地区における形態的観点からみた「特徵的 景観要素」の集合状況を示している。まとまり分布グラフでは、高 梁地区の中心を横切るように南北に「伝統継承型町家形式」が高さ を一定にして分布しているが、駅前付近には、「非伝統継承型町家形 式」が同様のまとまり高さをもって分布している。高梁地区では、 一般に「伝統継承型町家形式」の周囲には、「非伝統継承型商品型住 宅形式」が分布しており、特に駅前付近では突出してまとまり分布 が高い地点が存在する。そして、「非伝統継承型商品型住宅形式」の 合間には、「非伝統継承型集合住宅形式」が点在して分布している。 これらを図 6 で示したまとまり分布と比べてみると、伝統継承型が 中心となってはいるが、明らかに伝統継承型商品型の住宅形式及び 屋敷形式を、周囲の非伝統継承型が異種の景観の「まとまり」とし て増加し、侵食していることがわかる。特に駅前付近では非伝統継 承型が特徵的になっており、このことは、外部から電車で来た観光 客や来街者が駅を降りた時の第一印象として「歴史的街並みを感じ ることができない」根本的な原因となっている（図 11）。

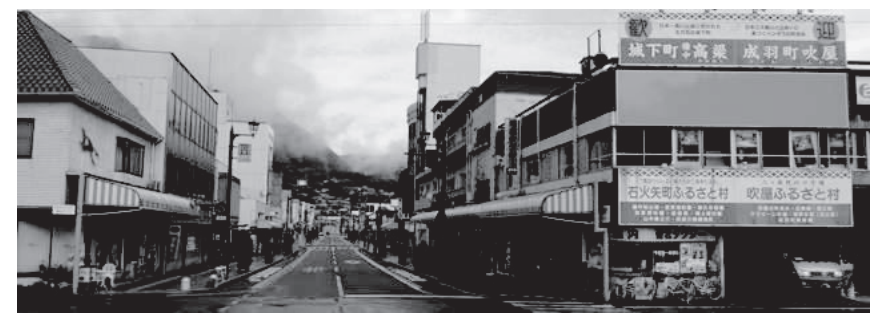

図 11 備中高梁駅・駅前の風景 c ）伝統継承型の類型化したまとまり分布の重ね合わせによる分析 伝統継承型のみのまとまり分布の重㸚合わせの分析を行うことに よって、伝統継承型の景観の「まとまり」がどのように構成されて いるのかを考察する (図 7 左)。町家形式が高梁地区の中心を横切る ように南北に分布し、さらにまとまり高さが高い。そしてその周辺 は商品型住宅形式が沿うように分布しており、同様にまとまり分布 グラフも沿うような高さとなっている。そして、この商品型住宅形 式が分布する地域もしくはその周辺には、屋敷形式が点在して分布 しており、商品型住宅形式のまとまり高さが低い部分を埋めるよう にまとまり高さを確保している。以上のように、町家形式が中心と なって大きな景観の「まとまり」を形成し、その周辺を商品型住宅 形式と屋敷形式が形成していることが読み取れる。

\section{7. まとまり分布グラフの断面ラインと連続立面図の比較分析}

まとまり分布グラフの分析により、「伝統継承型町家形式」は商家 町・本町地区を中心に南北に分布していた。本町地区は、町並み助 成の対象範囲であり、1999 年の制度創設から 10 年にわたり、32 件 の修景実績がある地区である。本町地区のまとまり分布グラフの断 面ラインを類型化した住宅形式毎に抽出し、町並み助成の修景効果 及び街並みの変化を検証した（図 8、9、10)。

町並み助成の修景効果として、まとまり分布グラフの断面ライン の 1998 年と 2010 年を比較すると、「伝統継承型町家形式」は全体的 にまとまりが増加しており、特に南側において、大きく増加してい ることが分かる。また「非伝統継承型町家形式」は北側を中心に全 体的にまとまりが減少傾向にあった。これは「伝統継承型町家形式」 だった建物が、老朽化等により建物ファサードを改築したために、 1998 年当時は「非伝統継承型町家形式」と判別されていたものが、 町並み助成によって修繥を行い、伝統継承型に戻ったことが大きな 要因となっていると考えられる。

また、「伝統継承型商品型住宅」は、1998 年にはまとまりが存在 しなかったのに対して、2010 年には一定のまとまりを確認できる。 これは建替えなどで商品型住宅が増えるが、街並みに配慮して可能 な限り伝統的素材を使用した住宅が増えたことが挙げられる。しか し、それ以上に「非伝統継承型商品型住宅形式」が全体的に大きく
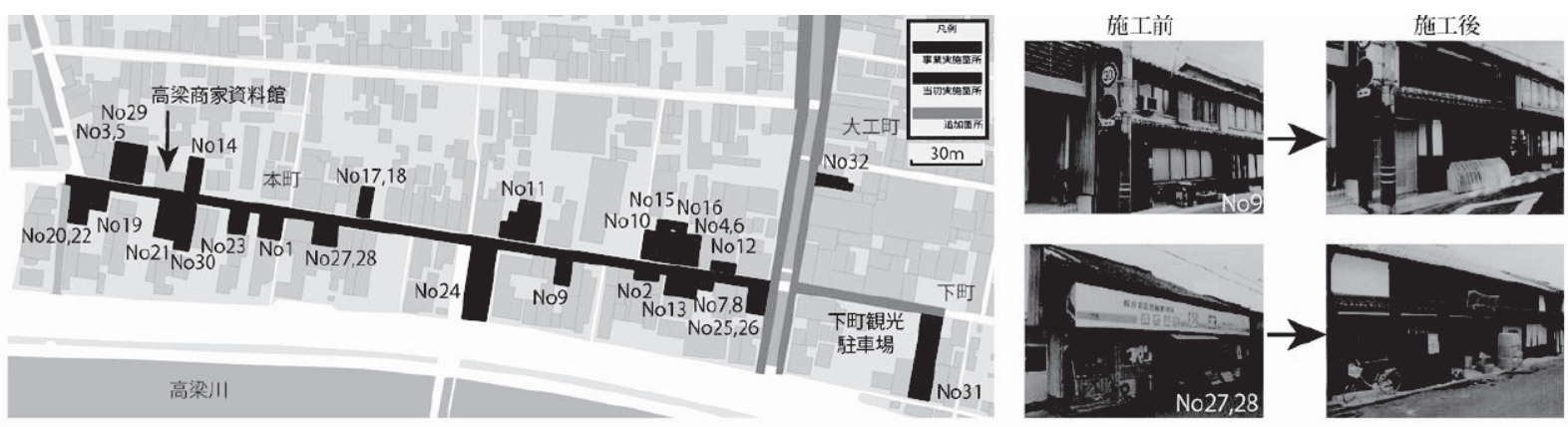

主な修景内容 ・開口の格子戸 - 付带工作物 (主に看板、 犬矢来等) ・外壁の材啠

保存整備事業実綪

\begin{tabular}{|c|c|c|c|c|c|c|c|c|c|c|c|c|c|c|c|c|c|c|c|c|c|c|c|}
\hline \multicolumn{24}{|c|}{ 保存整備事業実績 } \\
\hline 番号 & 年号 & 種別 & 事柴内容 & 番号 & 年号 & 種別 & 事業内容 & 番号 & 年号 & 種別 & 事業内容 & \begin{tabular}{|l|} 
噃号 \\
\end{tabular} & 年号 & 種别 & 事業内容 & 番号 & 年号 & 種別 & 事業内容 & 䧽号 & 年号 & 種別 & 事業内容 \\
\hline Nol & 10 & 修景 & 門没置 & \begin{tabular}{|l|} 
No7 \\
\end{tabular} & 11 & 修理 & 土藏 & No13 & 14 & 修理 & 保存修理 & No19 & 15 & 工作物 & エアコンカパー & No25 & 18 & 修理 & 保存修理 & No31 & 20 & 修理 & 保存修理 \\
\hline No2 & 10 & 修景 & 門設置 & \begin{tabular}{|l|} 
No8 \\
\end{tabular} & 11 & 修景 & $\begin{array}{ll}\text { 門設置 } \\
\end{array}$ & No14 & 14 & 修理 & 保存修理 & No2O & 16 & \begin{tabular}{|l|} 
修景 \\
\end{tabular} & \begin{tabular}{|l|l|l|l} 
修景 \\
\end{tabular} & No26 & 18 & 工作物 & 看板 & No32 & 21 & 修景 & 修景 \\
\hline No3 & 10 & 修理 & 保存修理 & No9 & 11 & 修理 & 保仔修理 & No15 & 15 & 修理 & 保存修理 & No21 & 16 & 修理 & 保存修理 & No27 & 19 & 修理 & 保仔修理 & & & & \\
\hline No4 & 10 & 修理 & 保存修理 & \begin{tabular}{|l|} 
Nol0 \\
\end{tabular} & \begin{tabular}{|l|}
12 \\
\end{tabular} & \begin{tabular}{|l|l|} 
修理 \\
\end{tabular} & 保存修理 & Nol6 & 15 & 修理 & 保存修理 & No22 & 16 & 工作物 & 看板 & \begin{tabular}{|l|} 
No28 \\
\end{tabular} & 19 & 工作物 & 看板 & & & & \\
\hline No5 & 10 & 工作物 & 在板 & \begin{tabular}{|l|} 
No11 \\
\end{tabular} & 12 & 修理 & 保存修理 & No17 & 15 & 修理 & 保存修理 & No23 & 16 & \begin{tabular}{|l|} 
修景 \\
\end{tabular} & 門設置 & No29 & 19 & 修理 & 保存修理 & & & & \\
\hline No6 & 10 & 工作物 & 看板 & No12 & 13 & 修景 & \begin{tabular}{|l|} 
門設置 \\
\end{tabular} & No18 & 15 & 工作物 & 看板 & No24 & 17 & 修理 & 保存修理 & No30 & 20 & 修理 & 保存修理 & & & & \\
\hline
\end{tabular}

図 12 高梁市町並夕保存地区整備事業修景実績 
増加したことが分かった。本町地区は用途地域が近隣商業地域、地 域地区が準防火地域に指定されているため、確認申請を要する修繥 や建替えを行う際は、伝統継承型の判断基準となっている木質系の 材料を使用することができず、非伝統継承型が増加していく結果に つながっていると考えられる。現行法規では、建築審查会と絡めた 市の条例を制定するか、建築協定を締結するかという方法で対応す るしかなく、町並み助成を有効に実行するための制度整備が必要で あることが分かった。また、「伝統継承型屋敷形式」のまとまりが減 少したのは、商家地区の町家様式を町並み助成のデザインガイドラ インとしたため、屋敷形式が建替えを行った際のルールを設けなか った点と、大規模な敷地の屋敷が税制対策などの理由から土地を分 筆し、ミ二開発的な建替えが行われたものと考えられる。

次に、町並み助成の制度を創設しなかった場合のシミュレーショ ンを行うために、本町地区の街並みの変化を想定した仮想モデルを 作成した。一般的に「伝統継承型町家形式」は、壁を共有している 隣家の建物が、空地や駐車場、また他の住居形式に変化すると、自 らも建替える傾向が強く、その際は法規の関係上、再び壁を共有す る町家形式とは成り得ず、先述した通り「非伝統継承型商品型住宅 形式」になる例が多く見られる。そのことから、1998 年の分布状況 において、「伝統継承型町家形式」の建物で隣家が空地もしくは他の 住居形式になっている 10 軒を抽出し、「非伝統継承型商品型住宅形 式」に変化したと想定して仮想のまとまり分布を作成した（図 9 )。 これは 1 年に 1 軒の割合で他の住居形式に変化したと仮定し、10 年 後の本町地区の街並みの「まとまり」の分布を示したものであるが、 「仮想モデル」と 2010 年のグラフと比較すると、2010 年のグラフ の方が「伝統継承型町家形式」は全体的に大きくまとまりが高くな り、「非伝統継承型商品型住宅形式」は全体的にまとまりが低くなっ ている。町並み助成制度がもし創設されていなかった場合、1998 年 から「仮想モデル」のようなまとまりの状態になっていた可能性が 高いことを考慮すると、現在の 2010 年の状況とは大きく異なってい たことを示しており、伝統継承型の建物が増加し、非伝統継承型の 建物が減少していることは、歴史的な街並み保全に対して、町並み 助成による景観コントロールは一定の効果があったと考えられる。

\section{8. まとめ}

（1）本研究では、高梁地区の景観データベースを元に住宅形式を 類型化し、その形式毎に「特徵的景観要素」の集積を示したまとま り分布グラフを描くことにより、景観構造の視覚化を行い、特にま とまりの高い地区・本町地区のデザインガイドラインを元にした町 並み助成の修景効果の検証を行った。同種の住宅形式の集積状況か ら、高梁地区のような明確な都市構造の把握や、用途地域などの法 制度による住宅形式の変化を読み取ることができた。このように一 定の特徵のある建築形式が面的に広がる地域に対して、その特徵的 な要素の集積状況を主軸とした同様の分析手法が適用可能であると 考えられる。

（2）町並み助成の修景効果の検証については、修景実績が 11 年で 32 件と実績数が上がってきただけで満足するのではなく、次の段階 として、街並み形成の効果計測をする必要がある。今回使用したま とまり分布グラフという手法により、住宅形式毎のまとまりを定量 的に視覚化することで、全体的なまとまりは増加し、一定の効果は
確認できたものの、確認申請を伴う改築や修縉などの際には、準防 火地域の不燃材料使用により、町並夕助成をしても「伝統継承型町 家形式」は減少していくという皮肉な結果となった。この課題は、 まとまり分布グラフの分析結果を冷静に受け止め、今後の景観計画 策定に向けた取り組みを軸に、行政・市民が意識を共有しながら、 問題に取り組んでいくことが望まれる。

（３）今後の高梁地区の街並み再生の展開について考えたときに、 今回試みたような「まとまり分布グラフ」および「まとまり分布グ ラフ断面ラインと連続立面の重衫合わせ分析」は、景観計画策定に 向けた住民ワークショップでの景観構造の視覚化支援ツールとして も有効であり、「歴史まちづくり法」事業検討時においても景観デー タベースを元にした街並み分析ツールとして活用できることが期待 される。また、「歴史まちづくり法」の事業推進や景観計画策定のプ ロセスの中で、事業後の景観構造をアセスメントとして予測できる ことから、同じ事業費を投入する場合に、どの事業から優先的に開 始すると最も効果的な景観改善を図ることが出来るかを評定するこ とが可能となる。これらの客観的な指標をもとに、市民と行政、地 域の専門家が景観ビジョンを共有し、ワークショップを重ねて進め ていくことが街並み景観の再生においては重要である。

あるコミュニティーという単位の中で、地域の特徴を強化して全 体の生活の質を上げるために、表層的な街並みに加え、「生活景」や 地域固有の文化や内部の生活がにじみ出した生きた街並夕等から、 街並みの何を大事にし、守り育てるかについて合意し、様々なレ心゙ ルにおける効果評定によるフィードバックを繰り返しながら街並み 景観の再生に取り組むことが望まれるが、今後このような分かりや すい支援ツールを活用することがその一助になれれば幸いである。

なお、本研究は 2009 2014 年科学研究費補助金基盤研究 (B)「地 域文化を活かす歴史的街並群再生のための工学的アプローチ」(研究 代表者：野口弘行）の一部として行われたものである。

注

注 1) 筆者らが作成した、参考文献 7）「高梁市歴史的風致維持向上計画」掲載 の図に一部加筆。

注 2) 街並みと町並みの用語の使い分けについては、様々議論されるが、本稿 では、「町並み」については、町並み助成制度の制度名に入っており、 また歷史的町並みのみを対象としている。それに対して、本稿の主題の 街並み再生の「街並み」は、歴史的町並みの意も含まれるが、城下町都 市である高梁市の場合は旧町割りが明確に残った歴史的町並みを中心と した旧市街地のほかに、新市街地を中心に新興住宅も新たな景観を形成 しており、本稿ではその全体像を捉えた「街並み」再生を研究対象とし ていることから、2 種の用語を使い分けて使用している。

\section{参考文献}

1）（社）日本建築学会編：景観法活用ガイド一市民と自治体による実践的景 観づくりのために,ぎょうせい発行, 2008

2) (社) 日本建築学会編: 生活景一身近な景観価値の発見とまちづくりー, 学芸出版社, 2009

3) 歴史まちづくり法研究会編纂: 歴史まちづくり法ハンドブック, ぎょうせ い発行, 2010

4) 守山基樹、門内輝行: 京都の街並み景観の記号化と記号のネットワークの 記述一街並みの景観における関係性のデザインの分析その 1 一, 日本建 
築学会計画系論文集 652 号, pp. 1507-1516, 2010.6

5) 古賀元也、鵤心治、多田村克己、大貝彰、松尾学: 景観まちづくりにおけ る空間イメージ共有手法に関する研究, 日本建築学会計画系論文集 633 号, pp. 2409-2416, 2008. 11

6) 関谷浩史、岡井敦、小林正美:市街地再生手法における目標空間イメージ 支援ツールの研究 (その 2) ：WEB 端末を活用した商店街再生計画案策定 のケーススタディ, 日本建築学会計画系論文集 576 号, pp. 37-44, 2004. 2

7) 高梁市: 高梁市歴史的風致維持向上計画, 2010

8) 東京芸術大学前野研究室編: 高梁-城下町備中高梁の歴史的町並夕, 岡山 県高梁市教育委員会, 1993

9）（社）日本建築学会編 小林正美他著：まちづくりデザインのプロセス, (社) 日本建築学会発行, 2005

10) 明治大学小林研究室編集: 本町におけるデザインガイドライン, 1999

11) 小林正美、古市修:「まちづくり」における「シャレットワークショップ」 の実験と評価に関する研究：岡山県高梁市における継続的ケーススタ ディー，（社）日本建築学会技術報告集, 15, pp. 283-288, 2002

12) 小浦久子:まとまりの景観デザイン 形の規制誘導から関係性の作法一, 学芸出版社発行，2008

13)正本彩子, 小浦久子: 京都都心地区における景観のまとまりに関する研究 市街地更新における歷史的環境特性の持続の視点から, 日本建築学会大 会学術講演梗概集, F-1, pp. 423-424, 2002

14) 土久菜穗, 山本明: 個性的景観形成のための歴史的建造物形態の類型的把
握手法 滋賀県近江八幡市八幡地区を事例として, 日本建築学会計画系論 文集，581 号，pp. 89-96，2004.7

15) 木多道宏，奥俊信，舟橋國男，鈴木毅，小浦久子: 街路景観における色彩 の心理効果 連続する建物群の基調色および単一建物の強調色の変化と

「まとまり」評価等との関係, 日本建築学会計画系論文集，522 号， pp. 239-246, 1999.8

16) 奥俊信: 街路景観構成要素と心理的効果との関係 主としてまとまりの良 さについて 街路景観の視覚特性ならびに心理的効果に関する研究 第 3 報, 日本建築学会計画系論文報告集，第 389 号，pp. 108-115，1988.7

17) 田中耕市: 平成 22 年度国土政策関係研究支援事業 研究成果報告書 地理 空間情報を活用した都市密度指標の確立一東京大都市圏を事例として 一, 国土交通省，2010

18) 古市修、小林正美:アーバン・インターベンションに関する研究 V-I - 都 市構造の視覚化の研究 (岡山県高梁市のケース) -, 日本建築学会大会学術 講演梗概集, F-1 分冊, pp. 905-906, 1999

19) 高橋顕也、古市修、小林正美:アーバン・インターベンションに関する研 究 IV - I 一都市粒子のスケールと密度に関する研究一, 日本建築学会 大会学術講演梗概集, F-1 分冊, pp. 933-934, 2000

20)布施昇、古市修、小林正美: 都市構造の視覚化に関する研究 I - II 一都市 粒子のスケールの際に関する研究一, 日本建築学会大会学術講演梗概集, F-1 分冊, pp. 399-400， 2002

（2011年 7 月10日原稿受理，2011年11月25日採用決定） 